\title{
Characterization of habitats based on algal periphyton biomass in the upper Paraná River floodplain, Brazil
}

\author{
Leandrini, JA. ${ }^{\mathrm{a}, \mathrm{b}}$, Fonseca, IA. ${ }^{\mathrm{b}}$ and Rodrigues, $L .^{\mathrm{b} *}$

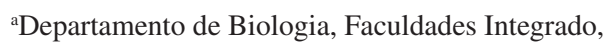 \\ BR-158, Km 207, CEP 87300-970, Campo Mourão, PR, Brazil \\ bDepartamento de Biologia, Núcleo de Pesquisa em Limnologia, Ictiologia e Aqüicultura, \\ Universidade Estadual de Maringá - UEM, \\ Av. Colombo, 5790, CEP 87020-900, Maringá, PR, Brazil \\ *e-mail: 1rodrigues@nupelia.uem.br \\ Received October 13, 2006 - Accepted March 1, 2007 - Distributed August 31, 2008
}

(With 5 figures)

\begin{abstract}
Considering the relevant role played by the hydrological regime on the structure and functioning of floodplains, this study aims at characterizing different types of aquatic environments according to periphyton biomass and evaluating the influence of the fluviometric levels of the Paraná River and other forcing functions upon the periphytic community. Periphyton (chlorophyll $a$ ) was analyzed in 28 habitats, during the years 2000 and 2001, in high and low water seasons. Both years were characterized by lacking the characteristic high water season. The Principal Components Analysis revealed two groups. The first component was positively associated with hydrometric level, electric conductivity, $\mathrm{pH}$ and transparency, and negatively with total nitrogen and total phosphorus, dissolved organic carbon and turbidity. The second component separated the habitats of Paraná River in the period of low waters from other environments, mainly for hydrometric level and high transparency values. Periphytic biomass of the habitats demonstrated that the maintenance of the functional integrity of the Upper Paraná River floodplain is closely related to its hydrologic cycle.
\end{abstract}

Keywords: periphyton, floodplain, biomass, Paraná river.

\section{Mudanças na biomassa de algas perifíticas na planície de inundação do alto Rio Paraná, Brasil}

\section{Resumo}

Tendo como princípio que o regime hidrológico é a principal função de força em planícies de inundação, este trabalho visa caracterizar diferentes ambientes através da biomassa da comunidade perifítica e relacionar a influência do nível hidrométrico sobre esta comunidade. Para isso, a biomassa perifítica (clorofila $a$ ) foi analisada em 28 habitats, sendo amostrados dois anos, 2000 e 2001, em diferentes períodos, águas altas e águas baixas. Na Análise de Componentes Principais, foram evidenciados dois grupos. O primeiro componente associado positivamente com o nível hidrométrico, condutividade elétrica, $\mathrm{pH}$ e transparência e, negativamente, com nitrogênio e fósforo total, carbono orgânico dissolvido e turbidez. O segundo componente separou os ambientes pertencentes ao rio Paraná, nos períodos de águas baixas, isto devido principalmente ao nível hidrométrico e à alta transparência. A biomassa perifitica dos habitats demonstra que a manutenção da integridade funcional da planície de inundação do alto rio Paraná está relacionada à maior manutenção de seu ciclo hidrológico.

Palavras-chave: perifíton, planície de inundação, biomassa, rio Paraná.

\section{Introduction}

The Paraná River, as the main active channel, is responsible for the drainage of the whole Paraná River upper basin, and its alluvial plain comprehends several fluvial habitats, such as swamps, ponds, secondary channels, marginal and temporary flooding dikes (Stevaux, 1993; Souza-Filho and Stevaux, 1997). Many of the marginal areas of those floodplain environments are colonized by aquatic macrophytes that propitiate the profuse development of the periphytic community. The periphyton is of great importance because this microbiota, by means of its metabolism, is involved in several important processes in the dynamics of aquatic ecosystems (Schwarzbold, 1990).

Spatial and temporal heterogeneity in an aquatic system can be evidenced through the periphyton by using species composition, biomass and productivity 
(Stevenson, 1997). Chlorophyll can also be considered as an efficient measurement in the evaluation of photosynthetic biomass of the phycoperiphytic community in aquatic habitats, and when related to physical and chemical factors, can be used as an indicator of the trophic conditions of the environments (Attayde and Bozelli, 1999).

Taking into account the effects of hydrological regimens on ecological processes of the floodplains, this study aimed at: a) characterizing different types of aquatic habitats in the floodplain according to periphyton biomass; and b) evaluating the influence of fluviometric levels of the Paraná River and other forcing functions on the photosynthetic biomass of the periphyton.

\section{Material and Methods}

The research was developed in the floodplain of upper the Paraná River, in the upper reaches of the Area of Environmental Protection of the Islands and Meadows of Paraná River, an area of 526,752 ha. During the years 2000 and 2001, during the seasons of high waters and low waters, different habitats representing the area were studied, including lentic habitats connected and disconnected with the main channel of the river, channels and main rivers of the system (Ivinheima, the Baia and the Paraná rivers; Figure 1). In each hydrological period two samplings were collected. A total of 28 environments were sampled: a) 13 in the Ivinheima River (three lotic habitats, five lentic habitats connected with the main river and five disconnected habitats); b) 11 in the Baia River (two in lotic habitats, five lentic habitats connected with the river and four disconnected habitats); and c) 4 in the Paraná River (one in the river, two lentic habitats connected with the river and one disconnected habitat) (Figure 1). This discrepancy among the number of environments studied in the rivers, mainly in the Paraná River, was due to the fact that this environment is mainly characterized by the presence of lotic habitats and the absence of the chosen substratum.

The collections of periphytic material (epiphyton) were taken from Eichhornia azurea Kunth, which is present in all environments studied and represents the most abundant macrophyte in the floodplain. The petioles were collected randomly, in different stands of macrophytes, in replicates (2) and conditioned in ice boxes in darkness to be transported to the laboratory.

At the laboratory, the periphyton was removed from the substratum and filtrated using Whatman GF/C fil-

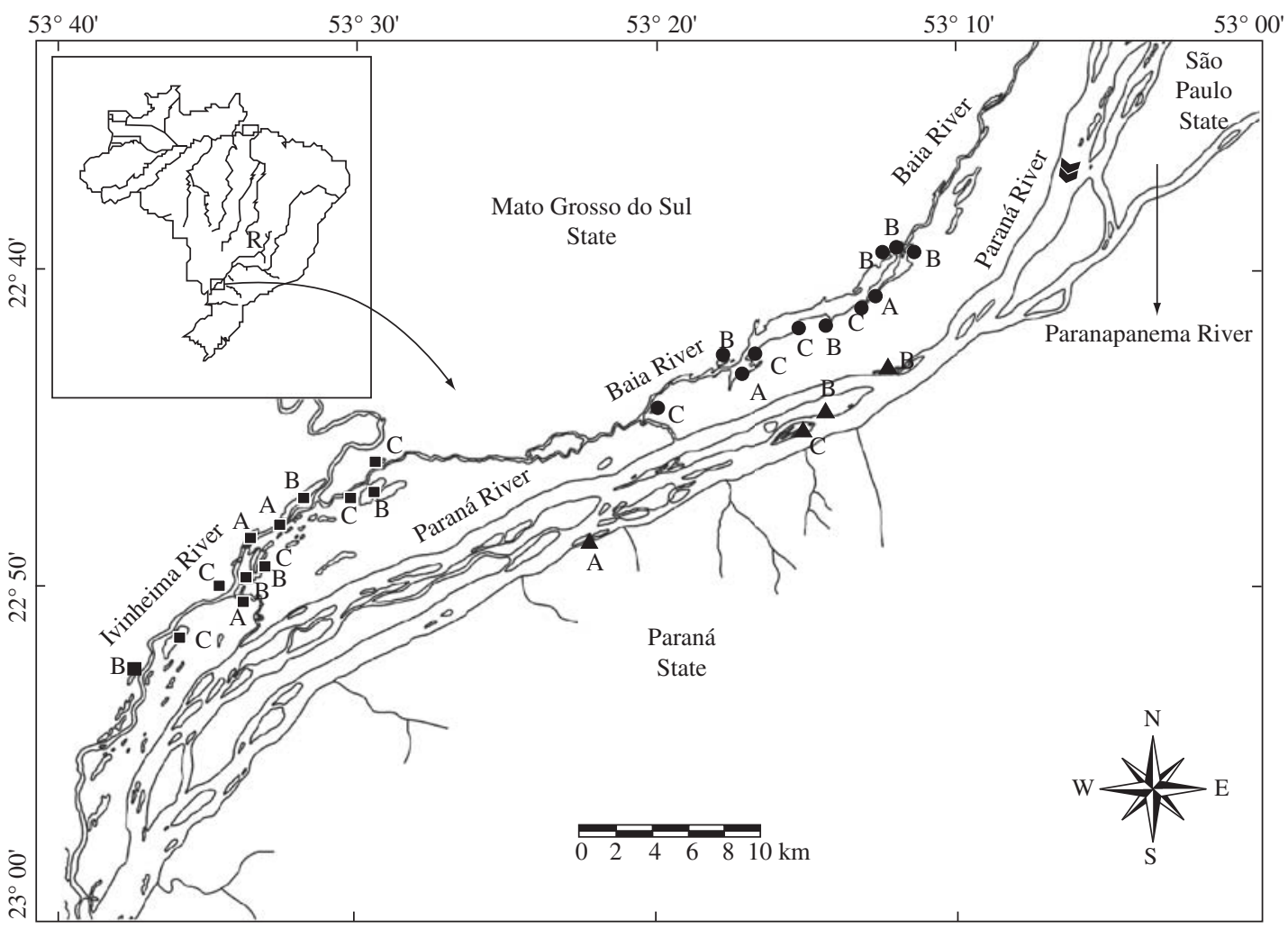

Figure 1. Locations of the sites sampled on the Paraná River $(\boldsymbol{\Delta})$, Ivinheima River ( $\boldsymbol{\bullet})$ and Baia River (•). A) River; B) Habitats with connection with the main channel of the river; and C) Habitats without connection with the main channel of the river. 
ters for analysis of photosynthetic biomass (such as chlorophyll $a$ ), according to Golterman et al. (1978).

The values of the fluviometric levels of the Paraná River were supplied by the Agência Nacional das Águas (ANA) and obtained in the meteorological station of Porto São José (Paraná State). Other abiotic parameters were also measured simultaneously and supplied by the Laboratory of Limnology of the Research Center on Limnology, Ichthyology and Aquiculture - Nupélia, at the State University of Maringá.

To compare the average biomass of the periphyton algae as related to the factors "year", "hydrological period" and "type of environments" (Ivinhema, Baia and Paraná rivers) an analysis of variance was applied (bifactorial ANOVA). For determining the significant minimum difference between year and hydrological period a multiple test of comparisons Tukey a posteriori was applied. The analyses were accomplished with the transformation of the data $\log 10(x+1)$, since results did not reach homocedasticity among the variances. For these analyses the software used was Statsoft (version 5.5).

Principal Components Analysis (correlation matrix) was used to ordain hydrological periods and environments, in the two years, as related to the limnological variables analyzed and the periphytic biomass. The software used was Pc-Ord, version 3.0 for Windows ${ }^{\circledR}$ (McCune and Mefford, 1997).

\section{Results}

The years of 2000 and 2001 were characterized by the absence of the characteristic flood, presenting, throughout both years, peaks of elevation of the water level associated to the operation of dams located upstream. However, the year 2001 presented a fairly long and accentuated period of low waters. On average, the water level of the Paraná River in this period remained at ca. $1.56 \mathrm{~m}$ (Figure 2).

The periphytic biomass differed significantly between the years 2000 and 2001 (Figure 3a), and among hydrological periods $(p=0.0035)$ and different environments of the rivers Paraná and Baia (Figure 3b). The habitats belonging to the Ivinhema River presented similarity with those on the Baia and Paraná rivers. However, significant interactions among the studied factors were not observed (Table 1).

In the 28 environments, divided into lentic (lagoons connected and disconnected with the main channel of the rivers) and lotic habitats, differences were observed throughout both years. In 2000, independently of the hy-

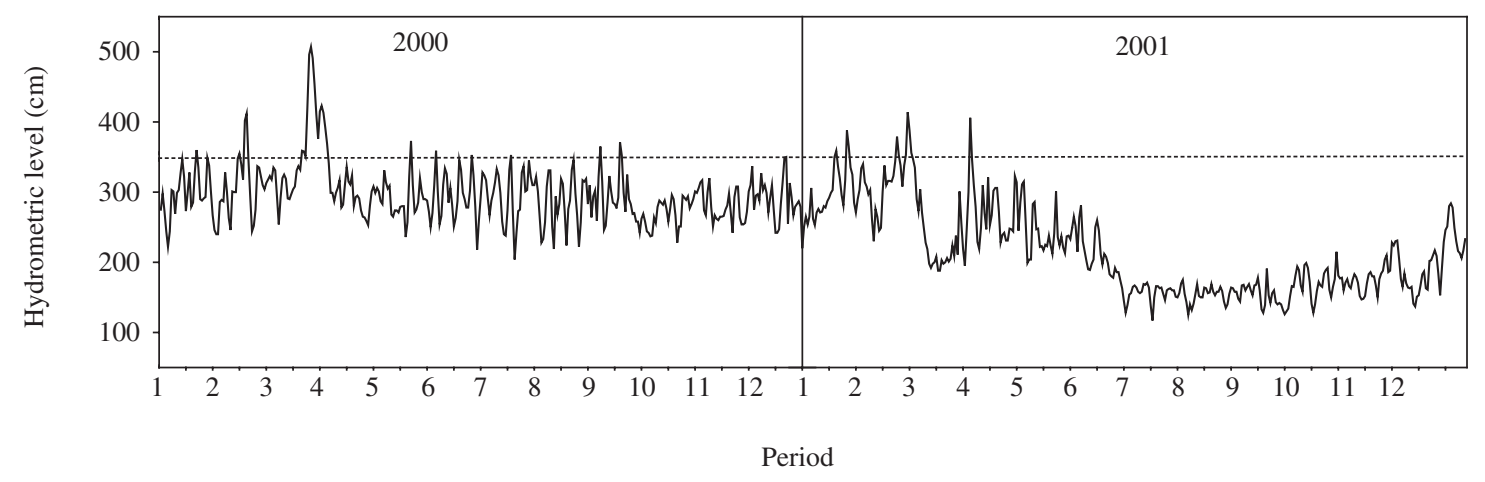

Figure 2. Hydrometric level of the Paraná River, during the years 2000 and 2001, in the Upper Paraná River Floodplain. Numeration represents the months of the year. Dotted line indicates the barrier of the homogenizing factor in the Upper Paraná River Floodplain. (Source: Agência Nacional de Águas - ANA).

Table 1. Influence of the variation sources on the periphytic biomass demonstrated through the bifactorial ANOVA. Values with asterisk indicate significant differences $(\mathrm{p}<0.05)$.

\begin{tabular}{lccc}
\hline \multicolumn{1}{c}{ Variation sources } & G. L. (effect; error) & F & P \\
\hline Environments & $2 ; 208$ & 4.53 & $0.0118^{*}$ \\
Hydrological periods & $1 ; 208$ & 11.91 & $0.0006^{*}$ \\
Years & $1 ; 208$ & 5.92 & $0.0157^{*}$ \\
Environments x hydrological periods & $2 ; 208$ & 2.74 & 0.066 \\
Environments x years & $2 ; 208$ & 0.039 & 0.9618 \\
Hydrological periods x years & $1 ; 208$ & 0.37 & 0.5386 \\
Environments x hydrological periods x years & $2 ; 208$ & 0.05 & 0.9432 \\
\hline
\end{tabular}



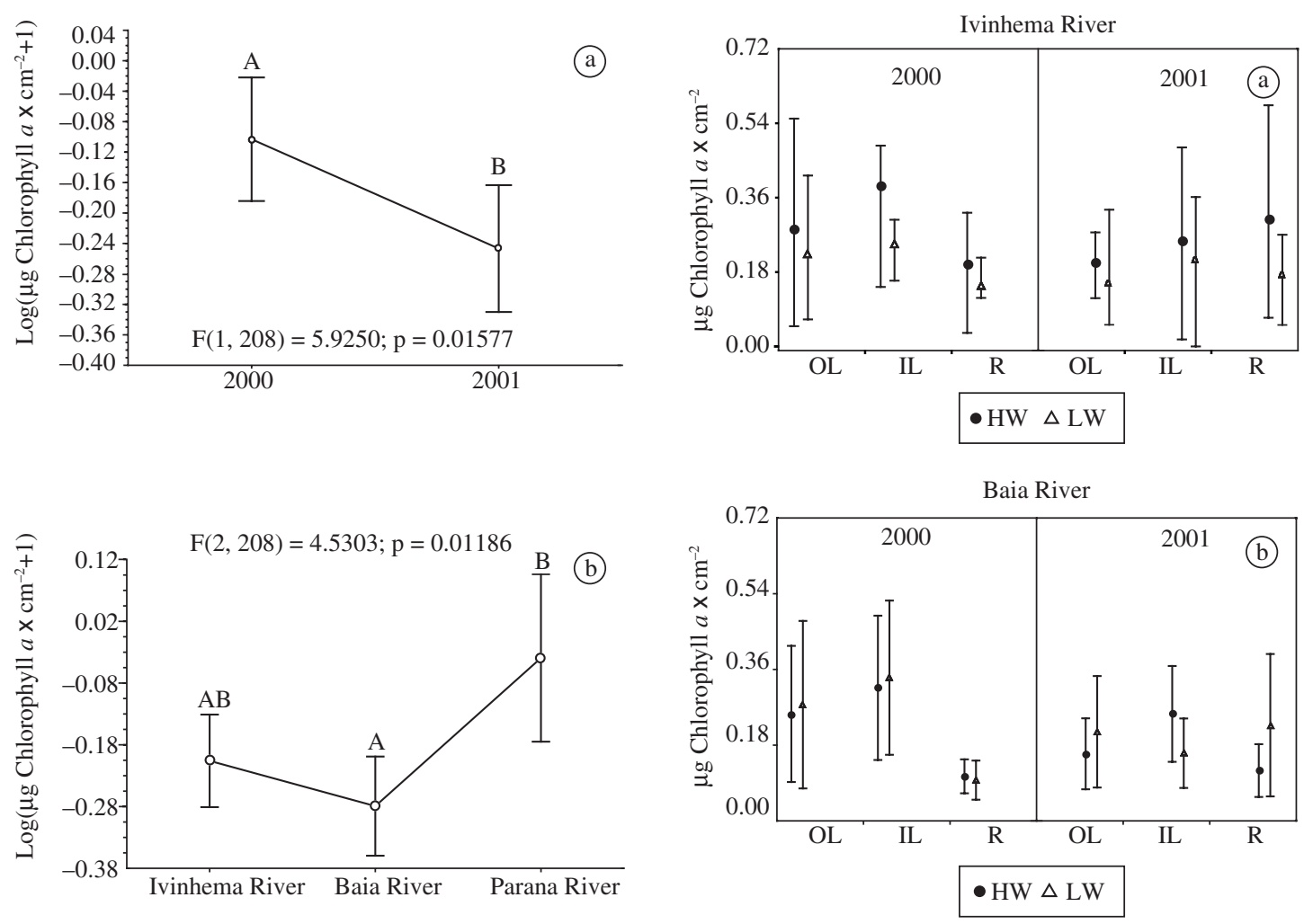

Figure 3. Effect of the year a) and system type b) factors on the chlorophyll in the upper Paraná River floodplain. The separated letters A and B indicate significant differences by the Tukey test $(\mathrm{p}<0.05)$. Mean \pm standard-deviation.

drological period, the habitats of the floodplain tended to display larger biomass in lentic environments, when compared to lotic ones. The lowest average value was observed for rivers and channels during the low water season. In 2001, there was a larger chlorophyll $a$ concentration of the periphyton in the lotic habitats, also independent of the period analyzed. For the disconnected lagoons, the average value found in the high water season, in 2001, was very close to the one recorded in 2000 , during the low water season.

Since the environments responded differently to alterations of the hydrometric level according to their degree of connection to the main river, the habitats were analysed separately according to their connection to the main channel.

In general, for the years 2000 and 2001, the habitats associated to the Paraná River presented higher average values of photosynthetic biomass (Figure 4).

The lentic and lotic environments, belonging to the Ivinheima and Paraná rivers, had the largest chlorophyll $a$ concentration during the high water season (Figures 4a,c). The habitats localized in the Baia River presented different behaviors among habitats and years studied (Figure 4b). In 2000, the connected and discon-

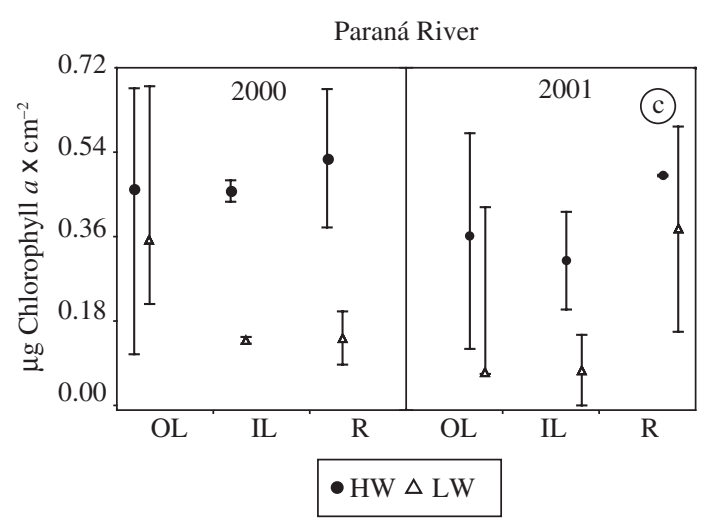

Figure 4. Standard - deviation and mean values of the chlorophyll a concentration $\left(\mathrm{mg} . \mathrm{cm}^{-2}\right)$ in lentic habitats (IL = isolated lagoons; $\mathrm{OL}=$ open lagoons) and lotic habitats ( $\mathrm{R}=$ rivers and secondary channels) of the a) Ivinheima, b) Baia and c) Paraná rivers, during the years of 2000 and 2001 in the upper Paraná River floodplain.

nected lagoons displayed greater values during the low water season and the lotic habitats during the high waters. In 2001, only isolated lagoons presented high values during the high water season. The remaining environments had larger values during the low water season.

The highest average values of photosynthetic pigments in the Ivinheima and Baia rivers, in 2000, were registered in isolated lagoons. In 2001, the lotic habitats of the Ivinheima River had more biomass, whereas in the 
Baia River more biomass was recorded in the disconnected lagoons. In the environments associated with the Paraná River, independently of the year considered, the lotic habitats always presented higher values of photosynthetic pigments (Figure 4).

The Principal Components Analysis summarized $46,2 \%$ of the total variability of the data in their first two axes, and showed two groups of data (Figure 5). The first component $(28.53 \%)$ was associated positively with the hydrometric level, conductivity, $\mathrm{pH}$ and transparency and negatively with total nitrogen and total phosphorus, dissolved organic carbon (DOC) and turbidy (Table 2). In this component the establishment of two groups is evident: a) the lotic and lentic environments (the connected ones) of the Paraná River, and the lotic environments of the Ivinheima River; and b) all the remaining environments belonging to the Baia River and the lentic environments of the Ivinheima River (disconnected lagoons or those connected with the main channel of the river).

The second component (17.74\%) separated the habitats of the Paraná River in the low water season from the remaining environments, especially for values of hydrometric level and high transparency.

\section{Discussion}

The flood pulses have a central role in the regulation of the biocenoses of river floodplain systems (Junk et al., 1989; Junk and Welcome, 1990; Thomaz et al., 1997, 2004), and the absence of high water seasons and the prevalence of low waters represent an important selection factor in the distribution, abundance and biomass of the organisms.

In the Upper Paraná River, oscillations of hydrometric level cause several flood pulses during the same hydrological cycle. On a weekly basis, several oscillations

Table 2. Correlations of the variables with the principal components I and II.

\begin{tabular}{lcc}
\hline \multicolumn{1}{c}{ Variable } & Axis 1 & Axis 2 \\
\hline $\mathrm{pH}$ & 0.3279 & -0.1906 \\
Temperature $\left(\mathrm{H}_{2} \mathrm{O}\right)$ & 0.0799 & -0.0244 \\
Transparency & 0.3018 & 0.499 \\
Conductivity & 0.3999 & -0.3447 \\
Hydrometric level & 0.2584 & 0.3232 \\
Alkalinity & 0.2536 & -0.5112 \\
Turbid & -0.4054 & -0.3356 \\
Oxygen & 0.1528 & 0.2381 \\
TN & -0.2342 & 0.1228 \\
TP & -0.2229 & -0.1339 \\
DOC & -0.4506 & 0.159 \\
Chlorophyll $a$ & 0.0938 & -0.0432 \\
\% Variation explained & 28.528 & 17.737 \\
Broken-stick & 3.103 & 2.103 \\
\hline
\end{tabular}

are caused by the operation of dams located upstream on the floodplain.

The years 2000 and 2001 did not present a characteristic hydrological cycle in the Upper Paraná River floodplain. The hydrometric level of Paraná River was almost always below $3.5 \mathrm{~m}$ (Figure 1). This level was considered by Thomaz et al. $(1997,2004)$ as the limit above which the river exercises larger influence on the habitats of the Upper Paraná River floodplain.

However, during peaks of water level, whether more or less intense, the littoral area of each environment should attain nutritional enrichment, probably due to more intense processes of decomposition associated to the flooding of vegetation and of its marginal dike, rich in organic matter, as well as of the resuspension of the sediment. However, Galat et al. (1998) found that high turbidity, high nutrients, and algal bloom in wetlands were often associated with periods of low inflow, shallow water, and resuspension of bottom sediments, mainly caused by the wind. With the increment of nutrients, probably an increase of the metabolic activity of the periphytic community occurred, with consequent increase of its biomass, independent of the seasonal period.

The environments associated to the Ivinheima and Paraná rivers presented larger values of photosynthetic biomass, always during the high water season. Values linked to the Baia River did not present any regularity. There are no dams in Ivinheima River and its hidrological cycle occurs in harmony with that of the Paraná River. During the years 2000 and 2001, the Paraná River did not flood enough so as to cause submersion of the Baia and Ivinheima Rivers (superior to $4.6 \mathrm{~m}$ ). Therefore, it is believed that the more accentuated increment and regulation of chlorophyll $a$ concentrations of the periphytic community in high waters, of both years, when compared with the Baia River, are associated to the absence of dams and to the natural flow of nutrients entering the system. That suggests that such regularity did not present significant differences in the two years considered due to the low pluviometric level that affected the whole area in the period of study.

The highest availability of nitrogen and, mostly, phosphorus, contributed to higher chlorophyll $a$ contents in the high water season for the sites at the Ivinheima River. Studies have shown that nutrients, especially phosphorus, are important for algal growth (Schindler, 1974; Allan, 1995; Pan et al., 1996; Winter and Duthie, 2000).

A fast, more accentuated and irregular increment of the chlorophyll $a$ concentrations in high waters than in low waters for the periphytic community was registered by Rodrigues and Bicudo (2004), who related it to the higher availability of nutrients and larger temperatures in the first period.

The Baia River is characterized by the low current speed and it enlarges considerably in the alluvial plain, presenting a temporary dynamics strongly influenced by the alterations of hydrometric levels of the Paraná River 


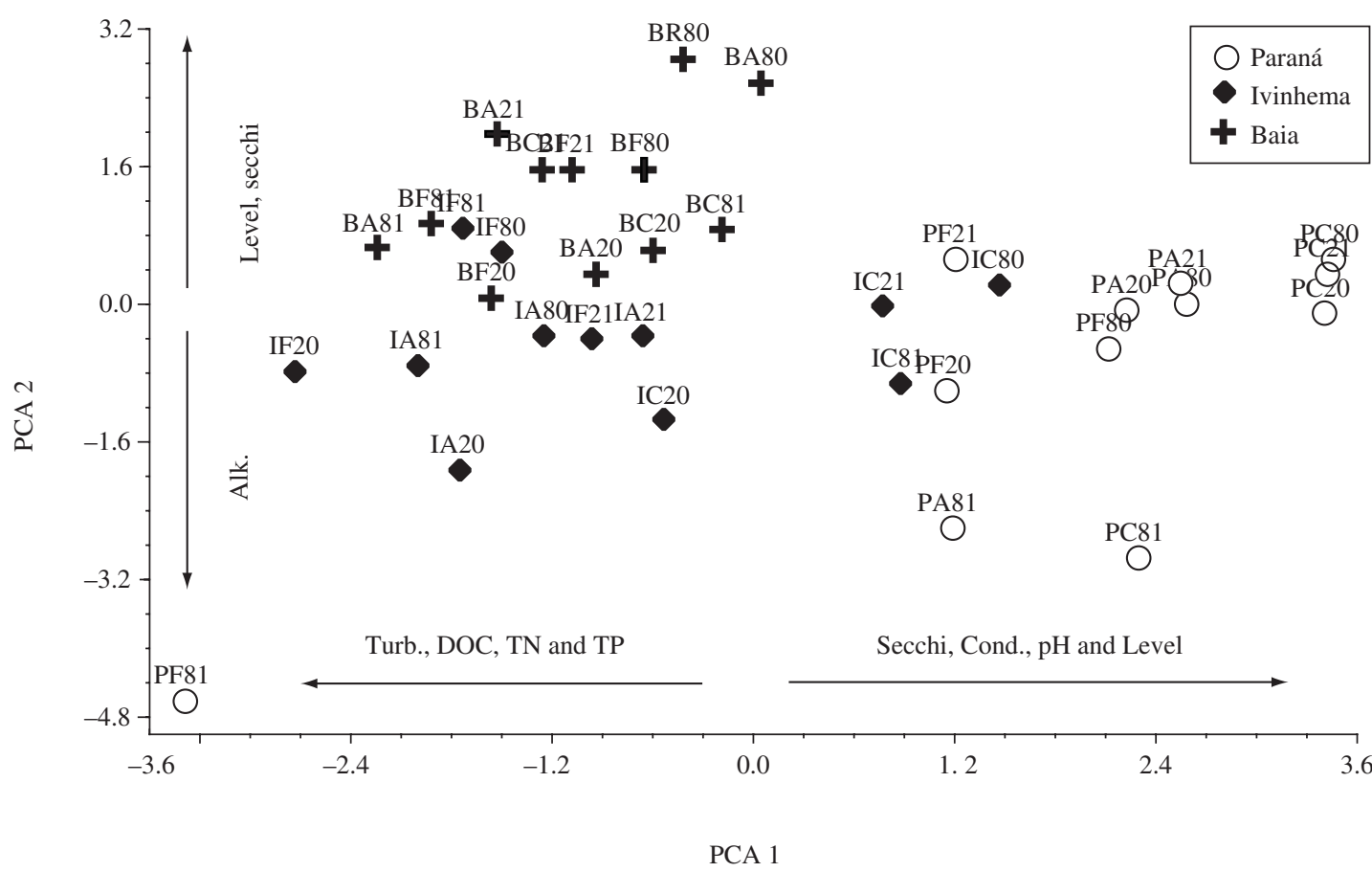

Figure 5. Principal component analyses (PCA) relating abiotic limnological factors to periphytic biomass, for 28 environments studied in the Upper Paraná River floodplain. Level = hydrometric level; TN = total nitrogen; TP = total phosphorus; DOC $=$ dissolved organic carbon; Turb. $=$ Turbid; Cond. $=$ conductivity, Alk $=$ alkalinity.

(Thomaz et al., 1997, 2004). As the years 2000 and 2001 were characterized by the absence of flood pulses, the environments of the Baia River presented very similar high values of nutrients in the studied periods, as well as low transparency of the water column, characteristic of the system during low water season. This fact caused the periphytic biomass to become more homogeneous, not differing among hydrologic periods in the years of the study.

Environments located in the Paraná River, as well as lotic habitats located in the Ivinheima River formed a single group. Despite nutritional resources being very important, the velocity of the currents is a key factor in determining the functional patterns of the periphytic communities in lotic systems (Biggs, 1996; Biggs and Thonsen, 1995). Reviewing available literature, Stevenson (1996) indicated that the largest biomass of algae in the periphyton is recorded in environments with moderate currents, in other words, between $10-50 \mathrm{~cm} / \mathrm{s}$. The velocity of currents in the lotic environments of the rivers Paraná and Ivinheima did not exceed $40 \mathrm{~cm} / \mathrm{s}$ average, which must have contributed to the proximity of the different years and hydrological periods. This level of currents has a stimulating effect on the periphyton (Riber and Wetzel, 1987; Wetzel, 1996), increasing by half the changes between the periphytic matrix and maintaining continuous changes of nutrient supply for the community and probably, favoring greater reproduction (Stevenson, 1997).
Summarizing, the data obtained for the periphytic biomass revealed that the maintenance of the functional integrity of the Upper Paraná River floodplain is closely related to the conclusion of its hydrologic cycle, reinforcing conclusions already established by Thomaz et al. (1997, 2004), Agostinho et al. (2000) and Rodrigues and Bicudo (2001), among others.

Acknowledgements - The authors thank the Research Nucleus in Limnology, Ichthology, and Aquaculture- Nupelia/PEA/UEM and the Brazilian agencies Capes and CNPq for their financial support of this work.

\section{References}

AGOSTINHO, AA., THOMAZ, SM., MINTE-VERRA, CV. and WINEMILLER, KO., 2000. In GOPAL, B., JUNK, WJ. and DAVIDS, J. (Eds.). Biodiversity in the high Paraná river Floodplain. Leiden: Backhus Publishers. p. 89-118

ALLAN, JD. 1995. Stream Ecology: Structure and Function of Running Waters. New York: Chapman \& Hall. 388 p.

ATTAYDE, JL. and BOZELLI, RL., 1999. Environmental heterogeneity patterns and predictive models of chlorophyll $a$ in a Brazilian coastal lagoon. Hydrobiol., vol. 390, no. 1-3, p. 129-139.

BIGGS, BJF., 1996. Patterns in benthic algal of streams. In STEVENSON, RJ., BOTHWELL, ML., LOWE, RL. (Eds.). Algal Ecology: freshwater benthic ecosystems. New York: Academic Press. p. 31-56. 
BIGGS, BJF. and THONSEN, HA., 1995. Disturbance of stream periphyton by pertubations in shear stress: time to structural failure and differences in community resistance. J. Phycol., vol. 31 , no. 2 , p. $233-241$.

GALAT, DL., FREDRICKSON, LH., HUMBURG, DD., BATAILLE, KJ., BODIE, JR., DOHRENWEND, J., GELWICKS, GT., HAVEL, JE., HELMERS, DL., HOOKER, JB., JONES, JR., KNOWLTON, MF., KUBISIAK, J., MAZOUREK, J., MCCOLPIN, AC., RENKEN, RB. and SEMLITSCH, RD., 1998. Flooding to restore connectivity of regulated, large-river wetlands. Natural and controlled flooding as complementary processes along the lower Missouri River. BioScience, vol. 48, no. 9, p. 721-733.

JUNK, WJ., BAYLEY, PB., SPARKS, RE., 1989. The flood pulse concept in river-floodplain systems. Can. J. Fish. Aquat. Sci., vol. 106, no. 1, p. 110-127.

JUNK, WJ. and WELCOMME, RL., 1990. Floodplains. In PATTEN, BC. (Ed.). Wetlands and shallow continental water bodies. The Hague, Netherlands: SPB Academic. 772 p.

GOLTERMAN, HL., CLYMO, RS. and OHMSTAD, MAM., 1978. Methods for physical and chemical analysis of freshwaters. Oxford: Blackwell Scientific. p. 491-524.

MCCUNE, B. and MEFFORD, MJ., 1997. Pc-Ord. Multivariate analysis of ecological data version 3.0. Oregon: MjM Software Design. $47 \mathrm{p}$.

PAN, Y., STEVENSON, RJ., HILL, BH., HERLIHY, AT. and COLLINS, GB., 1996. Using diatoms as indicator of ecological conditions in lotic systems: a regional assessment. J. North Am. Benthol. Soc., vol. 15, no. 4, p. 481-495.

RIBER, HH. and WETZEL, RG., 1987. Boundary-layer and internal diffusion effects on phosphorus fluxes in lake periphyton. Limnol. Oceonogr., vol.32, no. 6, p. 1181-1194.

RODRIGUES, L. and BICUDO, DC., 2001. Limnological characteristics comparison three systems with different hydrodynamic regime in the upper Paraná river floodplain, Brazil. Acta Limnol. Bras., vol. 13, no. 1, p. 1-25.

RODRIGUES, L. and BICUDO, DC., 2004. Periphytic Algae. In THOMAZ, SM., AGOSTINHO, AA. and HAHN, NS. (Eds.). The Upper Paraná River and its Floodplain. Maringá: EDUEM. p. 125-143.
SCHINDLER, DW., 1974. Eutrophication and recovery in experimental lakes: implications for lake management. Science, vol. 184 , no. 4139 , p. $897-899$.

SCHWARZBOLD, A., 1990. Métodos ecológicos aplicados ao estudo do perifíton. Acta Limnol. Bras. vol. 3, no. 1, p. $545-592$.

SOUZA-FILHO, EE. and STEVAUX, JC., 1997. Geologia e geomorfologia do complexo rio Baia, Curutuba, Ivinhema. In VAZZOLER, AEAM., AGOSTINHO, AA., and HANH, NS. (Eds.). A Planície de Inundação do Alto Rio Paraná. Maringá: EDUEM. p. 73-102

STEVAUX, JC., 1993. O rio Paraná: geomorfogênese, sedimentação, e evolução quaternária do seu curso superior (região de Porto Rico, PR). São Paulo: Universidade de São Paulo. 242 p. [Tese de Doutorado - Instituto de Geociências].

STEVENSON, RJ., 1996. Patterns of benthic algae in aquatic ecosystems. In STEVENSON, RJ., BOTHWELL, ML. and LOWE, RL. (Eds.). Algal Ecology: freshwater benthic ecosystems. New York: Academic Press. p. 3-26

-, 1997. Scale-dependent determinants and consequences of benthic algal heterogeneity. J. North Am. Benthol. Soc., vol. 16, no. 1 , p. 249.

THOMAZ, SM., ROBERTO, MC., BINI, LM., 1997. Caracterização limnológica dos ambientes aquáticos e influência dos níveis fluviométricos. In VAZZOLER, AEAM., AGOSTINHO, AA. and HANH, NS. (Eds.). A Planície de Inundação do Alto Rio Paraná. Maringá: EDUEM. p. 73-102

THOMAZ, SM., PAGIORO, TA., BINI, LM., ROBERTO, MC. and ROCHA, RRA., 2004. Limnological Characterization of the Aquatic Environments and the Influence of Hydrometric Levels. In THOMAZ, SM., AGOSTINHO, AA., and HAHN, NS. (Eds.). The Upper Paraná River and its Floodplain. Maringá: EDUEM. p. 75-102.

WETZEL, RG., 1996. Benthic algae and nutrient cycling in lentic freshwater ecosystems. In STEVENSON, RJ., BOTHWELL, ML. and LOWE, RL. (Eds.). Algal Ecology: freshwater benthic ecosystems. New York: Academic Press. p. 641-667

WINTER, JG. and DUTHIE, HC., 2000. Epilithic diatoms as indicators of stream total $\mathrm{N}$ and $\mathrm{P}$ concentration. J. North Am. Benthol. Soc., vol. 19, no. 1, p. 32-49. 